\title{
Majority of $T$. gondii seropositive chickens (Gallus domesticus) in Central Ethiopia carries the infective parasite
}

\author{
Endrias Zewdu Gebremedhin ${ }^{1 * \dagger}$, Gebregergs Tesfamaryam ${ }^{2+}$, Reta Duguma ${ }^{3}$, Getachew Tilahun ${ }^{4}$,
} Vincenzo Di Marco ${ }^{5}$ and Maria Vitale ${ }^{5}$

\begin{abstract}
Background: The prevalence of Toxoplasma gondii in free range chickens is a good indicator of the prevalence of T. gondii oocysts in the environment. The aim of this study was to isolate T. gondii parasites from heart and brain of seropositive free range (FR) chickens.

Findings: Isolation of $T$. gondii from pooled heart and brain of 41 direct agglutination test (DAT) positive ( $\geq 1: 40)$ free range chickens (Gallus domesticus) was carried out by bioassay in mice. T. gondii specific antibodies in mice were assayed by DAT and microscopy was employed for detection and enumeration of brain tissue cysts. Overall, bioassay was positive in 29 (70.7\%) chicken samples. T. gondii tissue cysts were isolated from 59\% (24/41) of bioassayed chickens: from 2 of 7 chickens with a titer of 1: $\leq 60,2$ of 5 with titer 1:180, 6 of 8 with titer 1:540, 10 of 15 with titer 1: 1620, 1 of 2 with titer 1:6000, 2 of 3 with titer 1:18000, 1 of 1 with titer 1:54000. None of the isolates was pathogenic for mice. Tissue cysts were detected from $61 \%$ of seropositive mice (DAT $\geq 1: 40$ ). Generally, tissue cyst counts per brain of mouse were low (mean: $132.7 \pm 84.4$; range: 47-352).

Conclusions: Majority of T. gondii seropositive chickens (Gallus domesticus) in Central. Ethiopia carries the infective parasite. Tissues from the free range chicken might be a source infection for animals and humans.
\end{abstract}

Keywords: Free range chicken, DAT, bioassay, Toxoplasma gondii, Central Ethiopia

\section{Findings}

Toxoplasma gondii is a zoonotic, obligate intracellular protozoan parasite that has the capacity to infect all warm blooded animals. Toxoplasmosis is usually subclinical; however the disease is an important cause of congenital problems and abortion in sheep, goats and women $[1,2]$

Bioassay in mice or cats has been used as a highly sensitive and specific test to isolate viable T. gondii. Recently, as an alternative to bioassay Opsteegh et al. [3] developed detection method using magnetic capture of $T$. gondii DNA followed by quantification of the parasite using quantitative real-time PCR.

So far two published information are available about isolation of viable $T$. gondii from any host in Ethiopia $[4,5]$.

\footnotetext{
* Correspondence: endrias.zewdu@gmail.com

${ }^{\dagger}$ Equal contributors

${ }^{1}$ Department of Veterinary Laboratory Technology, Ambo University, Faculty

of Agriculture and Veterinary Sciences, P.O.Box 19, Ambo, Ethiopia

Full list of author information is available at the end of the article
}

The present study was undertaken from September, 2012 to May, 2013 with the aim of isolation of T. gondii from heart and brain of seropositive free range (FR) chickens in Ambo, Adea and Fentale districts of Oromia Regional State, Central Ethiopia. Ambo district (37 $32^{\prime}$ to $38^{\circ} 3^{\prime} \mathrm{E}$ and $8^{\circ} 47^{\prime}$ to $9^{\circ} 20^{\prime} \mathrm{N}$ ) is found in West Shewa Zone while Adea $\left(38^{\circ} 58^{\prime} \mathrm{E}\right.$ to $39^{\circ} 22^{\prime} \mathrm{E}$ and $08^{\circ} 22^{\prime} \mathrm{N}$ to $\left.8^{\circ} 56^{\prime} \mathrm{N}\right)$ and Fentale $\left(39.93^{\circ} \mathrm{E}\right.$ to $39^{\circ} 56^{\circ} 0^{\prime \prime} \mathrm{E}$ and $8.975^{\circ} \mathrm{N}$ to $\left.8.58^{\prime} 30^{\prime \prime} \mathrm{N}\right)$ districts are located in East Shewa Zone of Oromia Region, Central Ethiopia.

Forty-one DAT positive backyard chickens out of 183 seropositive chickens identified during seroepidemiological study [6] were randomly sampled depending on willingness of owners to sell for the present study. The chickens were killed by cervical dislocation. Bioassay was performed as described by Dubey [2]. Briefly, the brain and heart of each 
chicken were pooled, homogenized, digested by incubating in acidic pepsin, filtered, centrifuged and the sediment neutralized with sodium bicarbonate. After another centrifugation the pellet was resuspended in saline mixed with penicillin $(1000 \mathrm{U} / \mathrm{ml})$ and streptomycin $(100 \mu \mathrm{g} / \mathrm{ml})$ and the suspension was inoculated intraperitoneally into Swiss white albino mice (National Veterinary Institute, Debre Zeit, Ethiopia). Five mice per chicken sample, a total of 205 mice, were used for the study. Five non-infected mice were kept separately as negative controls.

On day 45, surviving mice were bled during terminal anesthesia with di-ethyl ether (Biolab laboratories ltd, Israel). Blood samples were allowed to clot; centrifuged and sera were collected in cryovials. Sera samples were examined for the presence of antibodies (IgG) against $T$. gondii by the direct agglutination test (Toxoscreen DA, biomerieux ${ }^{\circ}$, France) following the protocol of the manufacturer. Sera were assayed at a screening dilution of 1:40 and 1:4000. A positive result at 1:40 or 1:4000 or both was considered indicative of $T$. gondii exposure.

Brains of all mice were examined for tissue cysts as described by Dubey [2]. Brains of all mice were removed by sagittal dissection, homogenized in $1 \mathrm{ml}$ phosphate buffer saline (PBS) $(\mathrm{pH}=7.2)$ by using a mortar and pestle and then examined for tissue cysts. The numbers of cysts in three aliquots of each $10 \mu \mathrm{l}$ were counted under

Table 1 Results of bioassay positive chicken samples ( $n=5$ mice/chicken sample)

\begin{tabular}{|c|c|c|c|c|c|c|}
\hline \multirow[t]{2}{*}{ District } & \multirow[t]{2}{*}{ Id } & \multicolumn{3}{|c|}{ Chicken } & \multirow{2}{*}{$\begin{array}{l}\text { DAT titer of } \\
\text { seropositive } \\
\text { chicken }\end{array}$} & \multirow{2}{*}{$\begin{array}{l}\text { Bioassay in mice } \\
\text { Seropositive mice } \\
\text { cyst positive mice }\end{array}$} \\
\hline & & Breed & Sex & Age in months & & \\
\hline \multirow[t]{16}{*}{ Ambo } & Ch159 & Local & $\mathrm{F}$ & 12 & 180 & 4,0 \\
\hline & Ch55 & Local & $F$ & 12 & 1620 & 3,1 \\
\hline & Ch52 & Local & $\mathrm{F}$ & 12 & 18000 & 5,1 \\
\hline & Ch140 & Local & $F$ & 12 & 1620 & 1,1 \\
\hline & Ch40 & Local & $\mathrm{F}$ & 12 & 1620 & 4,5 \\
\hline & Ch142 & Local & $\mathrm{F}$ & 12 & 1620 & 5,4 \\
\hline & Ch42 & Local & $\mathrm{F}$ & 9 & $\leq 60$ & 5,5 \\
\hline & Ch192 & Local & $\mathrm{F}$ & 11 & 1620 & 0,1 \\
\hline & Ch191 & Local & $\mathrm{F}$ & 12 & 54000 & 5,5 \\
\hline & Ch54 & Local & M & 8 & $\leq 60$ & 5,2 \\
\hline & Ch26 & Local & $\mathrm{F}$ & 8 & 540 & 5,4 \\
\hline & Ch28 & Local & $\mathrm{F}$ & 7 & 6000 & 5,0 \\
\hline & Ch38 & Exotic & $\mathrm{F}$ & 12 & 1620 & 4,3 \\
\hline & Ch31 & Local & $\mathrm{F}$ & 8 & 540 & 5,5 \\
\hline & Ch27 & Local & $\mathrm{F}$ & 9 & 18000 & 5,5 \\
\hline & Ch35 & Local & $\mathrm{F}$ & 6 & 1620 & 3,0 \\
\hline \multirow[t]{11}{*}{ Adea } & Ch310 & Local & M & 24 & 540 & 0,1 \\
\hline & Ch392 & Local & $\mathrm{F}$ & 13 & 540 & 5,1 \\
\hline & Ch414 & Local & $\mathrm{F}$ & 12 & 540 & 5,3 \\
\hline & Ch397 & Local & $\mathrm{F}$ & 9 & 1620 & 4,0 \\
\hline & Ch404 & Local & $\mathrm{F}$ & 10 & 540 & 5,3 \\
\hline & Ch411 & Local & $\mathrm{F}$ & 13 & 1620 & 4,1 \\
\hline & Ch396 & Local & $M$ & 8 & 180 & 5,4 \\
\hline & Ch331 & Local & $\mathrm{F}$ & 9 & $\leq 60$ & 3,0 \\
\hline & Ch348 & Local & M & 4 & 1620 & 4,1 \\
\hline & Ch330 & Local & $\mathrm{F}$ & 9 & 180 & 1,1 \\
\hline & Ch350 & Local & $\mathrm{F}$ & 4 & 1620 & 1,1 \\
\hline \multirow[t]{2}{*}{ Fentale } & Ch548 & Local & M & 12 & 1620 & 4,2 \\
\hline & Ch569 & Local & $\mathrm{F}$ & 9 & 540 & 1,1 \\
\hline
\end{tabular}


microscope with a 10X objective lens, summed and converted to a count per mouse brain [7]. A bioassay was considered positive if at least one $T$. gondii cyst was detected in any of the five inoculated mice or any of the mouse serum or mice sera reacted positively for DAT.

STATA version 11.0 for Windows (Stata Corp. College Station, USA) was used to analyze the data. Descriptive statistics were used to summarize the data. Association of cyst positivity (dependent variable) with independent variables (altitude, district, breed, sex, age, residence, and DAT titer of chicken) was assessed using Chi-square test and logistic regression. Non-collinear variables that presented a $P$-value of $<0 \cdot 25$ in univariable analysis were included in the multivariable logistic regression model. Results were considered significant at $P \leq 0.05$.

This research project was approved by the animal ethical committee of the College of Veterinary Medicine and Agriculture, Addis Ababa University.

Overall, bioassay was positive in 29 (70.7\%) chicken samples (22 samples were positive for both the tissue cysts and T. gondii specific antibodies; 5 samples were positive for serology alone and 2 samples were positive for cyst alone (Table 1). T. gondii was isolated from 24 $(59 \%)$ of 41 seropositive chicken $(\geq 1: 40)$ hearts and brains bioassayed in mice. Serological test (DAT) of survived mice $(n=204)$ revealed seropositive result in 100 (49\%) of the mice used for isolation, whereas tissue cysts were detected from 61 (61\%) of seropositive mice. Of the 204 mice brain examined microscopically, 61 (30\%) were positive for $T$. gondii tissue cysts (Table 1 ).

All inoculated mice survived the infection and manifested no clinical signs except 1 mouse which died 2 days post-inoculation perhaps due to infection or error during inoculation. All inoculated mice were examined microscopically for $T$. gondii regardless of DAT result. $T$. gondii parasites were isolated from 2 of 7 chicken with titer of $1: \leq 60,2$ of 5 with titer 1: 180, 6 of 8 with titer 1: 540,10 of 15 with titer 1:1620, 1 of 2 with titer1: 6000, 2 of 3 with titer 1:18000, 1 of 1 with titer 1:54000 (Table 1). Among the independent variables investigated at chicken level for association with cyst isolation rate, only DAT end titer of chicken was found to be significantly associated $(P<0.05)$ (Table 2$)$.

Among 61 cyst positive mice, 57 and 4 were DAT positive and negative, respectively. Among the cyst positive mice, the mean \pm standard deviation [SD] of cyst count per mice brain was $132.7 \pm 84.4$ (range: 47-353). The mean \pm SD of cyst count per mice brain was $123.4 \pm$ 89.9 for Adea district while it was $128.7 \pm 74.5$ and $136.6 \pm$ 84.5 for Fentale and Ambo districts, respectively. There was no significant difference in mean cyst count between districts.

Results of multivariable logistic regression analysis of predictors of cyst positivity in mice revealed that DAT positivity in mice, location of chicken (urban and periurban), midland altitude and age of chicken ( $\geq 13$ months) were independent predictors of cyst positivity (Table 3 ).

Sub-passage in mice or cell culture as well as cryopreservation of positive samples and permanent preparations were not done due to shortage of facilities. However, brain tissue homogenate of positive mice were kept deep frozen for future DNA extraction and genotyping elsewhere.

The high percentage of isolation of tissue cysts from seropositive chickens $(59 \%, 24 / 41)$ is as expected since poultry production using extensive management of FR

Table 2 Association of cyst positivity in mice after bioassay of chicken tissues with potential explanatory variables

\begin{tabular}{llll}
\hline $\begin{array}{l}\text { Variable and } \\
\text { category }\end{array}$ & $\begin{array}{l}\text { No. } \\
\text { examined }\end{array}$ & $\begin{array}{l}\text { No. cyst } \\
\text { positive (\%) }\end{array}$ & $\begin{array}{l}\text { 95\% confidence } \\
\text { interval }\end{array}$ \\
\hline District & & & \\
Fentale & 6 & $2(33.3)$ & $4.3-77.9$ \\
Adea & 15 & $9(60.0)$ & $32.3-83.7$ \\
Ambo & 20 & $13(65.0)$ & $40.8-84.6$
\end{tabular}

Altitude

Low land

Mid land

6

High land

25

2 (33.3)

$4.3-77.9$

10

16 (64.0)

$42.5-82.0$

Breed

Local

Exotic

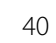

$23(57.5)$

$40.9-73.0$

Sex

Male

Female

33

5 (62.5)

24.5 - 91.5

Age

$\leq 6$ months

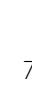

$19(57.6)$

$39.2-74.5$

7- 12 months

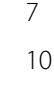

2 (28.6)

$3.7-71.0$

$\geq 13$ months

24

5 (50.0)

$18.7-81.3$

$48.9-87.4$

\section{Residence}

Rural

$10(45.5)$

$24.4-67.8$

Urban \& periurban 19

14 (73.7)

$48.8-90.9$

DAT end titer

180

540

1620

6000

18000

54000

$2(25.0)$

$3.2-65.1$

$5.3-85.3$

2 (40.0)

$59.0-1 * *$

$38.4-88.2$

$0-84.2^{* *}$

$9.4-99.2$

*DAT end titer of chickens was significantly associated with isolation of brain tissue cysts in mice $(P=0.037)$. The likelihood of cyst positivity is higher from chicken with high antibody titer, ${ }^{* *}$ one-sided $97.5 \%$ confidence interval. 
Table 3 Results of logistic regression analysis of predictors of $T$. gondii cyst positivity in mice

\begin{tabular}{|c|c|c|c|c|c|c|}
\hline \multirow[t]{2}{*}{ Variables } & \multirow[t]{2}{*}{ N (positive) } & \multirow[t]{2}{*}{$\%(P)$} & \multicolumn{2}{|l|}{ Univariable } & \multicolumn{2}{|l|}{ Multivariable } \\
\hline & & & OR $(95 \% \mathrm{Cl})$ & P-value & OR $(95 \% \mathrm{Cl})$ & P-value \\
\hline \multicolumn{7}{|l|}{ Altitude } \\
\hline Low land & $30(3)$ & 10.0 & 1.0 & - & 1.0 & \\
\hline Mid land & $124(31)$ & 25.0 & $3.0(0.85,10.58)$ & 0.088 & $\begin{array}{l}10.41(1.21 \\
89.46)\end{array}$ & 0.033 \\
\hline High land & $50(27)$ & 54.0 & $10.57(2.83,39.40)$ & $<0.001$ & $\begin{array}{l}1.51(0.19 \\
12.10)\end{array}$ & 0.699 \\
\hline \multicolumn{7}{|l|}{ Breed } \\
\hline Local & $199(58)$ & 29.15 & 1.0 & & & \\
\hline Cross \& exotic & $5(3)$ & 60.0 & $3.65(0.59,22.40)$ & 0.162 & $\begin{array}{l}1.13(0.11 \\
11.37)\end{array}$ & 0.919 \\
\hline \multicolumn{7}{|l|}{ Sex } \\
\hline Male & $40(10)$ & 25.0 & 1.0 & & & \\
\hline Female & $164(51)$ & 31.1 & $1.35(0.62,2.98)$ & 0.451 & & \\
\hline \multicolumn{7}{|l|}{ Age } \\
\hline$\leq 6$ months & $34(2)$ & 5.88 & 1.0 & & & \\
\hline 7-12 months & $50(6)$ & 12.0 & $2.18(0.41,11.52)$ & 0.358 & $\begin{array}{l}1.63(0.23 \\
11.42)\end{array}$ & 0.621 \\
\hline$\geq 13$ months & $120(53)$ & 44.17 & $12.66(2.90,55.23)$ & 0.001 & $\begin{array}{l}10.14(1.97 \\
52.06)\end{array}$ & 0.006 \\
\hline \multicolumn{7}{|l|}{ Residence } \\
\hline Rural & $110(25)$ & 22.73 & 1.0 & & & \\
\hline$U$ and Peri- $U$ & $94(36)$ & 38.30 & $2.11(1.15,3.88)$ & 0.0116 & $\begin{array}{l}3.78(1.17 \\
12.17)\end{array}$ & 0.026 \\
\hline \multicolumn{7}{|l|}{ W2W1 } \\
\hline$\leq 4.9 \mathrm{~g}$ & $104(30)$ & 28.85 & 1.0 & & & \\
\hline$\geq 5.0 \mathrm{~g}$ & $100(31)$ & 31.0 & $1.11(0.61,2.02)$ & 0.737 & & \\
\hline \multicolumn{7}{|l|}{$\begin{array}{l}\text { DAT titer of } \\
\text { chicken }\end{array}$} \\
\hline$\leq 540$ & $124(33)$ & 26.61 & 1.0 & & & \\
\hline$\geq 1620$ & $80(28)$ & 35.0 & $1.48(0.81,2.73)$ & 0.203 & $1.52(0.61,3.81)$ & 0.371 \\
\hline \multicolumn{7}{|l|}{$\begin{array}{l}\text { DAT status of } \\
\text { mice }\end{array}$} \\
\hline Negative & $104(4)$ & 3.85 & 1.0 & & 1.0 & \\
\hline Positive & $100(57)$ & 57.0 & $33.14(11.3,97.09)$ & $<0.001$ & $\begin{array}{l}25.87(8.05 \\
83.17)\end{array}$ & $<0.001$ \\
\hline
\end{tabular}

$D A T=$ direct agglutination test, $\mathrm{g}=$ gram, $\mathrm{N}=$ tested number, $\mathrm{P}=$ prevalence, $\mathrm{OR}=$ odds ratio, $\mathrm{U}$ and Peri- $\mathrm{U}=($ peri) urban, $\mathrm{W} 2 \mathrm{~W} 1=$ mean weight change of mice.

chickens is associated with $T$. gondii infection from the soil [2]. The present isolation rate was higher compared to 1 (2.3\%) of 43 seropositive chickens from Addis Ababa, Ethiopia [5]. The variation in isolation rate between the present study and that of aforementioned study might be attributed to difference in the age of the chickens studied, number of chicken examined, the number of mice inoculated, the burden of Toxoplasma in chicken and the type and amount of tissues bioassayed $[2,8,9]$. In this study, we used five mice per sample to inoculate pooled brain and heart tissue homogenate of seropositive chickens which might have increased our success of isolation $[9,10]$.

In the present study, T. gondii tissue cysts were detected from $61 \%(61 / 100)$ of seropositive mice while tissue cysts were observed in 2 DAT seronegative mice from 2 chickens. The logic behind the presence of cysts in the brain of seronegative mice could be due to low level of antibodies. Other possible reason can be due to the ability of $T$. gondii to escape immunity of host by avoiding fusion of lysosomes with phagocytes resulting in no or minimal antibody response [11]. The number of 
seropositive mice could have been higher if the cut-off value of DAT used was lower than 1:40 because viable $T$. gondii has been isolated from chicken with a DAT titer of $1: 10$ or even $1: 5$ elsewhere $[9,12]$. In contrary to the above, some seropositive mice $(39 \%)$ had no cysts. This can be due to the small number and size of cysts in brain of mice which can be missed during counting of cysts under microscope [8]. Furthermore, the low sensitivity of microscopy, the low volume of brain examined under the microscope $(30 \mu \mathrm{l})$, the absence of concentration method, and not performing further passaging of tissues of the mice without detectable cysts could have contributed for the absence of cysts from seropositive mice.

No clinical toxoplasmosis was observed in the mice during the monitoring period. This might suggest that most of the T. gondii strains circulating in the study area are not pathogenic to Swiss albino mice, T. gondii isolates in this study were not type I phenotypically or the dose of the parasite in the inoculated tissue homogenate of chicken was low. Similar finding has been reported from Addis Ababa, Ethiopia [5].

In accord with our findings, low cyst count was reported from FR chickens of Colombia, South America [13] and Ghana [10]. It has also been reported that poultry generally harbor less tissue cysts as compared to sheep, goats and pigs [14].

\section{Conclusions}

T. gondii parasites are widespread in free range chickens of Central Ethiopia. This indicates that the environment is contaminated with $T$. gondii oocysts and that meat from free range chickens might be a source of infection for humans and other hosts. The local T. gondii isolates were not pathogenic for mice by bioassay. Altitude, DAT positivity of mice, age and urban and periurban location of chicken were independent predictors of cyst positivity in mice.

\section{Competing interest}

The authors declare that they have no competing interests.

\section{Authors' contributions}

EZG and GT conceived and designed the proposal, collected, tested and analyzed the data and drafted the article. RD, GT, MV and V di M participated in the study design and edition of the article. All authors read and approved the final manuscript.

\section{Acknowledgements}

The financial support of Addis Ababa University (combating HIV/AIDS and promoting maternal and child health project) is acknowledged.

\section{Author details}

'Department of Veterinary Laboratory Technology, Ambo University, Faculty of Agriculture and Veterinary Sciences, P.O.Box 19, Ambo, Ethiopia. ${ }^{2}$ Jigjiga University, College of Veterinary Medicine, P.O.Box 307, Jigiiga, Ethiopia. ${ }^{3}$ Department of Clinical Studies, Addis Ababa University, College of Veterinary Medicine and Agriculture, P.O.Box 34, Debre Zeit, Ethiopia. ${ }^{4}$ Addis Ababa University, Aklilu Lemma Institute of Pathobiology, P.O.Box 1176,
Addis Ababa, Ethiopia. ${ }^{5}$ Italian National Reference Centre for Toxoplasmosis at Istituto Zooprofilattico Sperimentale della Sicilia A. Mirri, Palermo, Italy.

Received: 8 May 2014 Accepted: 3 September 2014

Published online: 24 September 2014

\section{References}

1. OIE: Toxoplasmosis. In OIE Manual of Diagnostic tests and Vaccines for Terrestrial Animals, Vol. 2. Paris, France: Office International Des Epizooties; 2008:1286

2. Dubey JP: Toxoplasmosis of Animals and Humans. 2nd edition. Florida: U.S.A. CRC Press; 2010.

3. Opsteegh M, Langelaar M, Sprong H, den Hartog L, De Craeye S, Bokken G, Ajzenberg D, Kijlstra A, van der Giessen J: Direct detection and genotyping of Toxoplasma gondii in meat samples using magnetic capture and PCR. Int J Food Microbiol 2010, 139:193-201.

4. Dubey JP, Choudhary S, Tilahun G, Tiao N, Gebreyes WA, Zou X, Su C: Genetic diversity of Toxoplasma gondii isolates from Ethiopian feral cats. Vet Parasitol 2013, 196:206-208.

5. Tilahun G, Tiao N, Ferreira LR, Oliveira S, Verma SK, Kwok OCH, Molla B, Saville WJA, Medhin G, Kassa T, Aleme H, Gebreyes WA, Dubey JP: Seroprevalence of Toxoplasma gondii from free-range Chicken (Gallus domesticus) from Addis Ababa, Ethiopia. J Parasitol 2013, 99:740-741.

6. Gebremedhin EZ, Tesfamaryam G, Yunus HA, Duguma R, Tilahun G, Di Marco V, Vitale M: Seroepidemiology of Toxoplasma gondii infection in free range chickens (Gallus domesticus) of Central Ethiopia. Epidemiol Infect,in press. doi:10.1017/S0950268814000971.

7. Fritz H, Barr B, Packham A, Melli A, Conrad PA: Methods to produce and safely work with large numbers of Toxoplasma gondii oocysts and bradyzoite cysts. J Microbiolo Methods 2012, 88:47-52.

8. Dubey JP, Rajendran C, Costa DG, Ferreira LR, Kwok OC, Qu D, Su C, Marvulo MF, Alves LC, Mota RA, Silva JC: New Toxoplasma gondii genotypes isolated from free range chickens from the Fernando De Noronha, Brazil: unexpected findings. J Parasitol 2010, 96(4):709-712.

9. Dubey JP, Su C, Oliveira J, Morales JA, Bolaños AV, Sundar N, Kwok OCH, Shen SK: Biologic and genetic characteristics of Toxoplasma gondii isolates in free-range chickens from Costa Rica, Central America. Vet Parasitol 2006, 139:29-36.

10. Dubey JP, Huong LT, Lawson BWL, Subekti DT, Tassi P, Cabaj W, Sundar N, Velmurugan GV, Kwok OCH, Su C: Seroprevalence and Isolation of Toxoplasma gondii from free range chickens in Ghana, Indonesia, Italy, Poland, and Vietnam. J Parasitol 2008, 94:68-71.

11. Waree P, Ferguson DJ, Pongponrat NE, Chaisri U, Sukthana Y: Immunohistochemical study of acute and chronic toxoplasmosis in experimentally infected mice. Southeast Asian J Trop Med Public Health 2007, 38:223-231.

12. Dubey JP, Graham DH, Blackston CR, Lehmann T, Gennari SM, Ragozo MA, Nishi SM, Shen SK, Kwok OC, Hill DE, Thulliez P: Biological and genetic characterization of Toxoplasma gondii isolates from chickens (Gallus domesticus) from São Paulo, Brazil: unexpected findings. Int J Parasitol 2002, 32:99-105

13. Dubey JP, Gomez-Marin JE, Bedoya A, Lora F, Vianna MCB, Hill D, Kwok $\mathrm{OCH}$, Shen SK, Marcet PL, Lehmann T: Genetic and biologic characteristics of Toxoplasma gondii isolates in free-range chickens from Colombia, South America. Vet Parasitol 2005, 134:67-72.

14. Tenter AM, Heckeroth AR, Weiss LM: Toxoplasma gondii: from animals to humans. Int J Parasitol 2000, 30:1217-1258.

doi:10.1186/s13028-014-0060-4

Cite this article as: Gebremedhin et al: Majority of T. gondii seropositive chickens (Gallus domesticus) in Central Ethiopia carries the infective parasite. Acta Veterinaria Scandinavica 2014 56:60. 